\title{
Chronic high dose of captopril induces depressive-like behaviors in mice: possible mechanism of regulatory $\mathbf{T}$ cell in depression
}

\author{
Hyun-Sun Park ${ }^{1, *}$, Arum Han ${ }^{1, *}$, Hye-Lim Yeo ${ }^{1,4}$, Min-Jung Park ${ }^{1}$, Min-Jung You ${ }^{1}$, \\ Hyun Jin Choi ${ }^{3}$, Chang-Won Hong ${ }^{5}$, Sang-Hyuk Lee ${ }^{2}$, Seung Hyun Kim ${ }^{4}$ Borah Kim² \\ and Min-Soo Kwon ${ }^{1}$ \\ ${ }^{1}$ Department of Pharmacology, School of Medicine, CHA University, Seongnam-si, Gyeonggi-do, Republic of Korea \\ ${ }^{2}$ Department of Psychiatry, CHA Bundang Medical Center, CHA University, Seongnam-si, Gyeonggi-do, Republic of Korea \\ ${ }^{3}$ College of Pharmacy, CHA University, Seongnam-si, Gyeonggi-do, Republic of Korea \\ ${ }^{4}$ Cell Therapy Center and Department of Neurology, College of Medicine, Hanyang University, Haengdang-dong, Seoul, \\ Republic of Korea \\ ${ }^{5}$ Department of Physiology, School of Medicine, Kyungpook National University, Daegu, Gyeongbuk, Republic of Korea \\ *These authors have contributed equally to this work \\ Correspondence to: Borah Kim, email: genie@cha.ac.kr \\ Min-Soo Kwon, email: minsoo100@cha.ac.kr \\ Keywords: depression, regulatory T cell, cytokines, angiotensin II, captopril \\ Received: January 05, $2017 \quad$ Accepted: July 06, $2017 \quad$ Published: August 03, 2017 \\ Copyright: Park et al. This is an open-access article distributed under the terms of the Creative Commons Attribution License 3.0 \\ (CC BY 3.0), which permits unrestricted use, distribution, and reproduction in any medium, provided the original author and source \\ are credited.
}

\section{ABSTRACT}

Major depression has various types of symptoms and disease courses with inconsistent response to monoamine-related antidepressants. Thus, monoamine theory may not be the only pathophysiologic pathway relevant to depression. Recently, it has been suggested that regulatory T cell (Treg) is associated with depression. Based on our previous study that showed decreased regulatory $\mathrm{T}$ cell (Treg) population following chronic high-dose captopril (CHC, $40 \mathrm{mg} / \mathrm{kg} / \mathrm{day} * 21$ days) administration, we examined whether $\mathrm{CHC}$ alone can induce depressive-like behaviors in mice even without stressful stimuli. In this study, we found that CHC induced depressive-like behaviors in tail suspension test (TST) and forced swimming test (FST) without systemic illness, while it did not induce anhedonic behavior, anxiety-like behaviors, or sociality-related behavior. The depressive-like behaviors were rescued by either CHC washout or antidepressant. CHC caused reduction in foxp 3 and gata 3 mRNA expression in the lymph nodes with elevation in plasma IL-1 $\beta$ and IL-6. Interestingly, $\mathrm{CHC}$ increased serum angiotensin II level. In the hippocampus, CHC increased TNF-a and IL-6 mRNA expression with microglia activation while reduced glucocorticoid receptor expression. However, CHC did not affect to hippocampal kynurenine pathway, serotonin level, hypothalamic corticotropin-releasing hormone mRNA level, or serum corticosterone level. Consequently, we propose that $\mathrm{CHC}$ may induce a specific form of depressive-like behaviors via Treg reduction and microglial activation.

\section{INTRODUCTION}

Major depression is one of the most disabling and chronic psychiatric diseases in the modern society. Global
Burden of Disease studies from 1990, 2000 and 2010 has identified depression as one of the leading causes with disability and a risk factor that contributes to suicide and ischemic heart disease $[1,2]$. 
Nevertheless, current treatment for depression is still based on "monoamine hypothesis" which bears several limitations. The monoamine hypothesis is based on the findings that antidepressants, such as tricyclic antidepressants (TCAs) and norepinephrine/serotonin reuptake inhibitors (N/SRI), can enhance monoamine levels in the CNS [3]. However, monoamine hypothesis alone appears to be insufficient to completely expain the depression pathophysiology due to some limitations such as non-responsiveness, recurrence and side effects $[4,5]$. Thus, there is an urgent necessity to identify new pathophysiologic target to develop new medications for depression.

Recently, "cytokine theory" was emerged and attempted to explain pathomechanism of depressive disorder with immunologic factors $[6,7]$. There are several evidences that elevated serum and CNS pro-inflammatory cytokines, such as IL- $1 \beta$, IL- 6 , IFN- $\gamma$, and TNF- $\alpha$ or increased inflammation response are associated with depressive symptom or severity of disease [8-11]. These factors not only serve a role as mediators of peripheral inflammation but also communicate with the CNS as an inflammation inducer in the CNS. Kynurenine (KYN) pathway has been suggested as a factor linking "cytokine theory" and "monoamine theory" in depression. The enzymes involved in KYN pathway, such as indoleamine 2,3-dioxygenase (IDO), kynurenine aminotransferase (KAT) and kynurenine monooxygenase (KMO, sometimes referred as kynurenine hydroxylase) are strongly associated with cytokines [7, 12]. Activation of KYN pathway by pro-inflammatory cytokines induces the degradation of tryptophan, finally leading to serotonin depletion [7]. In addition, quinolinic acid, a constituent of KYN pathway, was also found to act as NMDA receptor agonist and exhibited depressive features, such as decreased reaction time and difficulties in learning [13]. Thus, change in circulating and the CNS cytokines may be additional candidates involved in depression pathophysiology.

Microglia, innate immune cells and major cytokines producer in the CNS, are found to communicate with the peripheral immune system and may be associated with depressive disorder $[14,15]$. Studies using positron emission tomography (PET) imaging showed microglial activation in depressed patients, who committed suicide [16, 17]. Moreover, it is reported that lipopolysaccharide (LPS), which can activate microglia, can also induce depressivelike symptoms [18]. The functional phenotype of microglia is also involved in depression and stress vulnerability $[19,20]$. These results suggest the possibility that factors associated with regulation of microglial function, such as cytokines [21], angiotensin II (ANG II) [22] and endothelin [23], can be hints to solve the complicated pathophysiology of major depressive disorder.

Among peripheral immune cells, regulatory $\mathrm{T}$ cells (Treg, CD4+ CD25+ Foxp3+) have been known to modulate the immune system, including functional phenotypes of microglia [24, 25], and they exhibit neuroprotective effects by inhibiting inappropriate or excessive immune responses [26, 27]. In addition, we reported that $\mathrm{T}$-cell depleted nude mice and chronically restraint stressed mice with Treg and T Helper 2 cells (Th2) reduction exhibited stress vulnerability with microglia dysfunction, which may be associated with depression recurrence [19]. Treg depletion with antiCD25 antibody in mice also could contribute to depressive symptoms [26]. Furthermore, anti-inflammatory cytokines, which can be released by Treg, block the development of endotoxin-induced behavioral alterations [13]. Thus, it is speculated that peripheral Treg dysfunction may possibly be involved in depression by affecting microglia functional phenotypes [28].

Captopril is angiotensin converting enzyme inhibitor that suppresses conversion of angiotensin I to angiotensin II. Also, captopril is used for hypertension treatment by suppressing renin-angiotensin-aldosterone system (RAAS) that is known to regulate blood pressure. In our previous study, we found that chronic high-dose captopril (CHC) decreased intratumoral CD4+ CD25+ Foxp3+ Treg [29], and this finding may be independent of previously known function of captopril. Based on several papers that reported a possible association between decreased Treg population and depression patients [30-32], we hypothesized that CHC may induce a specific form of depressive-like behaviors via Treg reduction and microglial activation.

\section{RESULTS}

\section{Chronic high dose captopril (CHC) induced depressive-like behaviors in TST and FST}

Based on previous studies about association between the reduction in Treg population with depressivelike behaviors and studies that found chronic high dose captopril (CHC) can reduce Treg population, series of experiments to identify the effect of captopril on mice behavior were performed. Captopril at concentration of $40 \mathrm{mg} / \mathrm{kg}$ was administered to mice by dissolving in drinking water for 7, 14, and 21 days and we performed TST and FST to confirm time-course effect of high dose of captopril on depressive-like behavior of mice. Both FST and TST are the most frequently used tests to evaluate the depression-like behaviors in rodents [33]. In both FST and TST, mice encounter an inescapable stress and the elevation of immobility time means helpless immobile behaviors, which reflects depressive-like mood of mice. Captopril-treated mice began to show depressivelike behaviors after 21 days of high dose captopril administration in TST and FST and the immobility time observed in the CHC mice was similar to that of CRS mice (Figure 1A, 1B). We also examined dose-dependent effect of captopril on depressive-like behaviors. Figure $1 \mathrm{C}$ and $1 \mathrm{D}$ showed that $40 \mathrm{mg} / \mathrm{kg}$ of captopril increased immobility time in both of TST and FST, while $25 \mathrm{mg}$ / 
$\mathrm{kg}$ of captopril did not alter the immobility time. Hence, chronic high-dose of captopril treatment (CHC) was defined as administering $40 \mathrm{mg} / \mathrm{kg}$ of captopril for more than 21 days and $\mathrm{CHC}$ increased depressive-like behaviors of mice in TST and FST. Captopril washout for 7 days after $\mathrm{CHC}$ discontinuation restored depression-like behaviors in TST and FST (Figure 1E, 1F). To evaluate antidepressant effect of imipramine on $\mathrm{CHC}$-induced depressivelike behavior, tricyclic antidepressant imipramine was treated during $\mathrm{CHC}$ administration or after induction of depressive-like behaviors by $\mathrm{CHC}$. The increased immobility time caused by $\mathrm{CHC}$ was attenuated by cotreatment of imipramine with $\mathrm{CHC}$ in both of TST and FST (Figure 1G, 1H). To evaluate antidepressant effect of imipramine after induction of depression-like behavior by $\mathrm{CHC}$, imipramine was treated for 14 days with additional captopril after 21 days of captopril treatment and this procedure is referred to as 'post-treatment of imipramine'. During the post-treatment imipramine experiment, captopril in drinking water was administered continuously because captopril washout normalizes immobility time in TST and FST. Post-treatment of imipramine for 14 days to the $\mathrm{CHC}$ mice restored increased immobility time in both TST and FST (Figure 1I, 1J). In addition, the anhedonic behavior of mice was assessed by sucrose preference test. Sucrose preference test (SP) is well-established behavior test to examine depressive-like symptom, especially anhedonia, with TST and FST [34]. Interestingly, CHCmice did not exhibit anhedonic behavior (Figure 1K).

\section{Chronic high dose captopril (CHC) did not affect to anxiety and sociality in mice}

The behaviors associated with anxiety and sociality were assessed by EPM, LD, and social interaction test. In contrast to depressive-like behaviors, $\mathrm{CHC}$ did not affect anxiety and sociality in mice. There were no significant differences between the controls and CHC groups in EPM, LD, and SI (Supplementary Figure 2A-2C).

In order to investigate the possible toxicity induced from $\mathrm{CHC}$, we examined general condition of mice by measuring body weight, serum GOT and evaluating motor activity by rotarod test. The body weight was decreased in $\mathrm{CHC}$ mice in agreement with previous study [35] and was increased slightly by captopril washout (Supplementary Figure 2D). There were no differences between the controls and $\mathrm{CHC}$ mice in serum GOT level and motor activity (Supplementary Figure 2E, 2F).

\section{Chronic high dose captopril (CHC) decreased regulatory $\mathrm{T}$ cell (Treg) populations in the spleen and affected the peripheral immune system}

To confirm the effect of $\mathrm{CHC}$ on Treg population, Treg population in mice was measured by flow cytometry. In accordance with our previous study [29], CHC decreased
Treg population in the spleen (Figure 2A). In addition, peripheral inflammation was found to have possibility to induce depressive symptoms $[6,26,36,37]$. Thus, we analyzed mRNA markers related to various subtypes of $T$ cells in the mesenteric lymph nodes and serum cytokine profile associated with inflammation. The mRNA expressions of gata3 and foxp3, which are markers of Th2 and Treg respectively, were decreased in the mesenteric lymph nodes of $\mathrm{CHC}$ mice and there were no significant alterations in tbx21 (T Helper 1 cells) mRNA expressions (Figure 2B). In addition, CHC increased circulating IL$1 \beta$ and IL-6 levels (Figure 2D, 2E), while there were no alterations in other inflammatory cytokines such as TNF- $\alpha$, IL-17, IL-4, IL-10 and IFN- $\gamma$ (Figure 2C, 2F-2I). Also, serum angiotensin II (ANG II) level was measured to investigate the effect of CHC on ANG II. However, serum ANG II levels in CHC mice were increased in CHC mice in spite of inhibition effect of captopril on angiotensin converting enzyme (ACE) (Figure 2J).

\section{CHC mice exhibited increased microglial activation in the hippocampus but not in the hypothalamus}

The hippocampus is widely known as the key brain region involved in depression $[33,38]$. To identify the effect of $\mathrm{CHC}$ in this area, we investigated the change in inflammatory cytokines and microglia. TNF- $\alpha$ and IL-6 mRNA levels were increased in the hippocampus of $\mathrm{CHC}$ mice (Figure 3A) and were restored by co-imipramine treatment (Figure 3B). Brain-derived neurotrophic factor (BDNF), KYN pathway-related factors (IDO, $\mathrm{KAT}, \mathrm{KMO}$ ), microglia functional phenotype markers (CX3CR1, CD200r, p2ry12), angiotensin receptors (AT1a, 1b, 2), and serotonin receptors (5-HT1a, 2a) were not altered by $\mathrm{CHC}$ in the hippocampus (Figure $3 \mathrm{~A}$ ). The change in number and morphology of microglia were analyzed by immunohistochemical staining with Iba1. Figure $3 \mathrm{C}$ showed that $\mathrm{CHC}$ increased the number of microglia (Iba-1 positive cell) in the hippocampus. Moreover, $\mathrm{CHC}$ mice showed more ramified microglia and the change was reversed by imipramine co-treatment. The protein level of GR in the hippocampus was also measured to identify the influence of $\mathrm{CHC}$ on the hippocampus. Many researchers reported that pro-inflammatory cytokine such as TNF- $\alpha$ can decrease glucocorticoid receptor (GR) level and result in glucocorticoid resistance [39]. Figure 3D described that CHC decreased GR protein level in the hippocampus. To identify the effect of $\mathrm{CHC}$ on other brain area and determine the extent of inflammatory reaction in brain, the hypothalamus of mice, which is well-known depression-related area, was analyzed with qPCR and immunohistochemistry. Figure $3 \mathrm{E}$ and $3 \mathrm{~F}$ showed that CHC did not altered mRNA expressions of inflammatory cytokines and the number of microglia (Iba-1 positive cell) in the hypothalamus. 


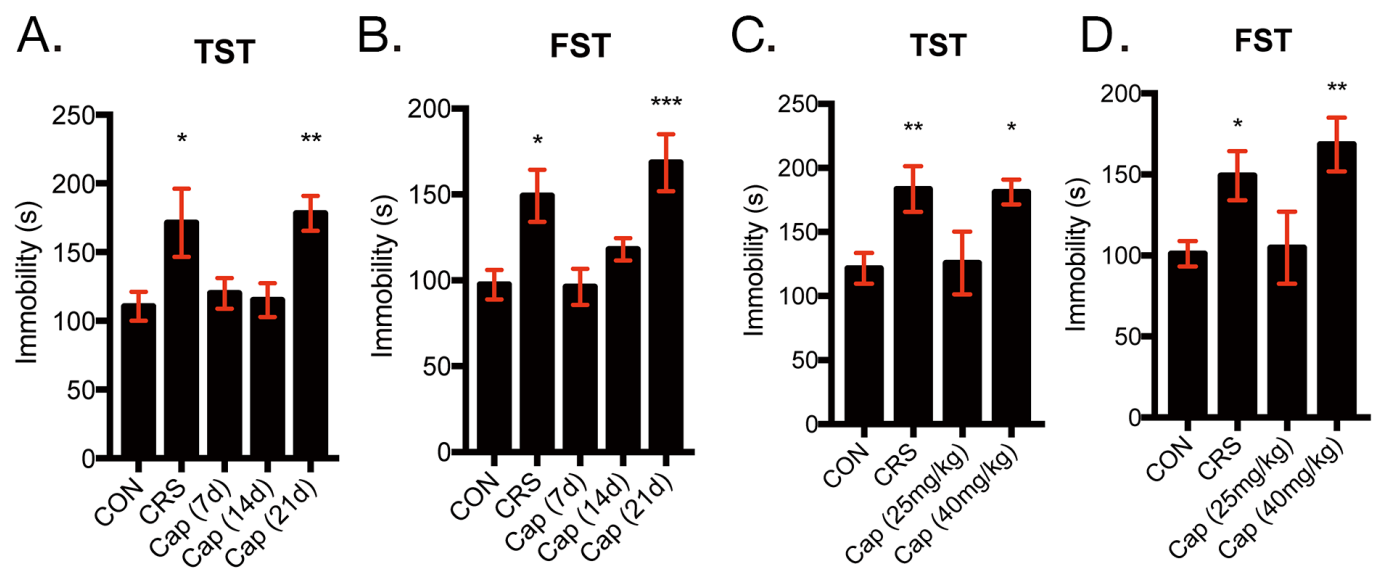

E.

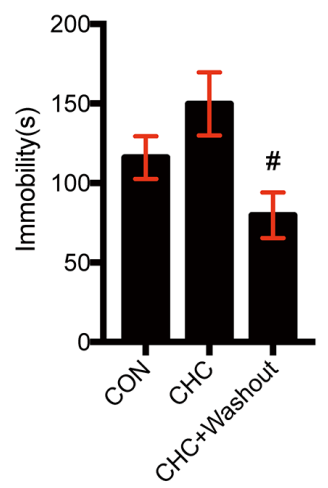

I.

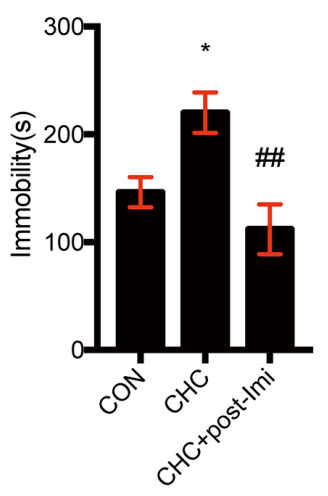

F.

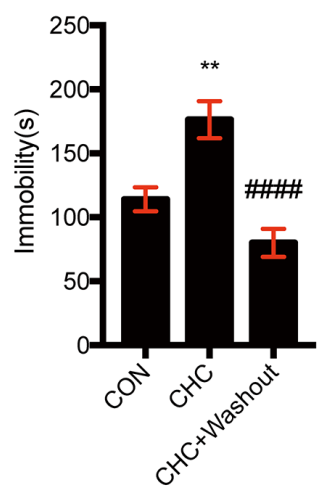

J.

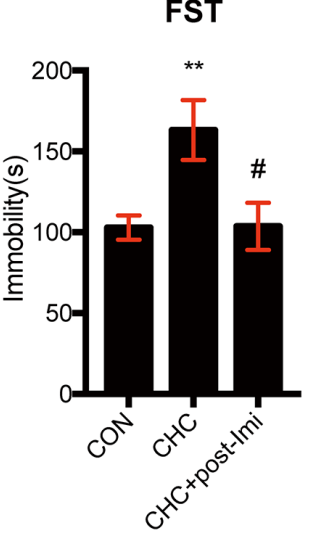

G.

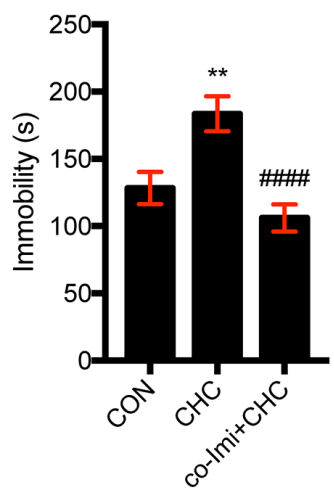

H.

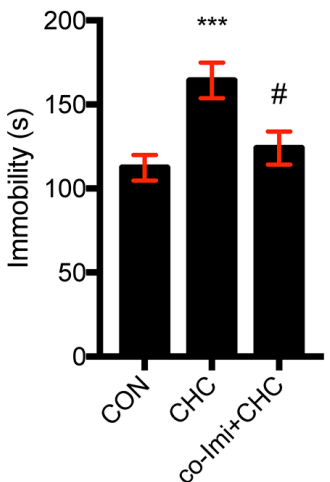

K.

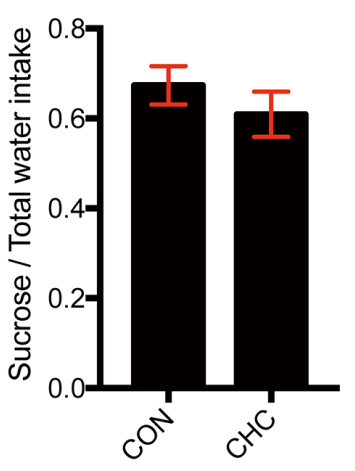

Figure 1: Chronic high-dose captopril (CHC) induced depressive-like behavior in mice. The time-course effect and dosedependent effect of captopril were examined by observing depression-like behavior in mice by TST and FST. Mice were administrated with captopril (40 mg/kg) for 7, 14, 21 days and their behavior was assessed with TST (A) and FST (B) and $\mathrm{n}=10-20$ in each group. Mice were also administrated with 25 or $40 \mathrm{mg} / \mathrm{kg}$ of captopril for more than 21 days and their behavior was assessed with (C) TST and (D) FST and $\mathrm{n}=10$ - 20 in each group. Chronic high-dose captopril (CHC) is defined as $40 \mathrm{mg} / \mathrm{kg}$ of captopril in drinking water for 21 days or more and all behavior tests were performed within a week after $\mathrm{CHC}$ administration. Captopril administration was continued during behavioral test. The effect of captopril washout for 7 days after the end of CHC was assessed by TST (E) and FST (F) and $n=10-15$ in each group. The effect of imipramine co-treatment (Co-Imi) during CHC was assessed by TST (G) and FST (H) and n $=22-27$ in each group. The effect of imipramine post-treatment (Post-Imi) was assessed by TST (I) and FST (J) and $n=7-14$ in each group. Sucrose preference test (SP) for $1 \%$ sucrose solution over regular drinking water was examined for 2 days after 2 days of inhabitation to two bottle conditions (K). The data shown are mean \pm SEM. $* \mathrm{p}<0.05,{ }^{* *} \mathrm{p}<0.01,{ }^{* * *} \mathrm{p}<0.001$ compared with the controls. $\# \mathrm{p}<0.05, \# \# \mathrm{p}<0.01, \# \# \# \mathrm{p}<0.0001$ compared with the CHC- treated groups. 
A.

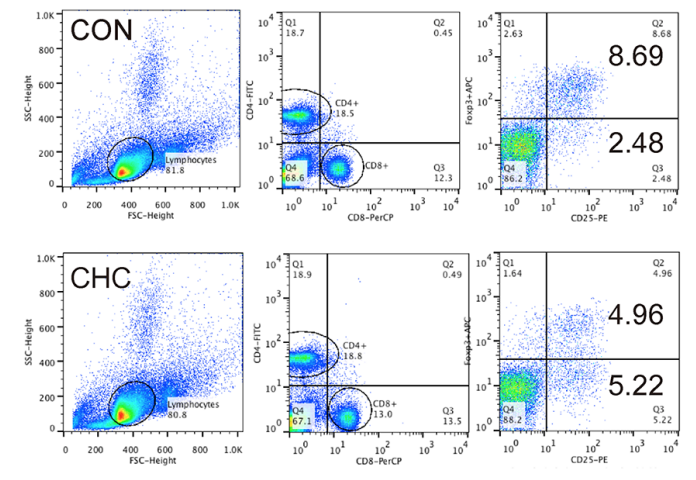

C.

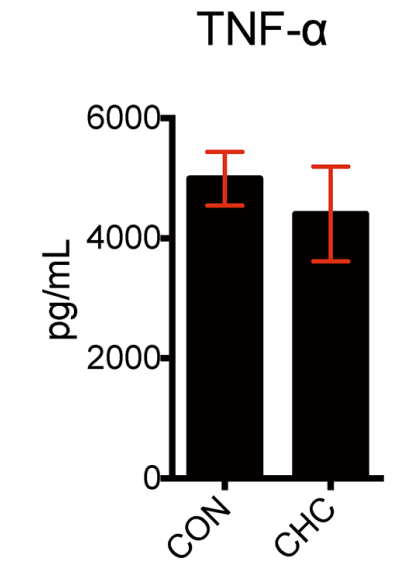

G.

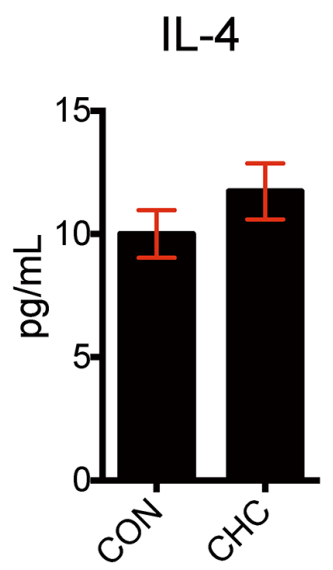

D.

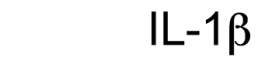

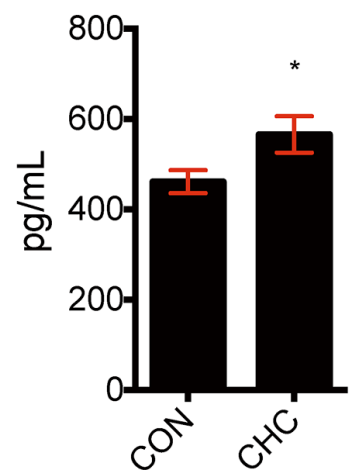

H.

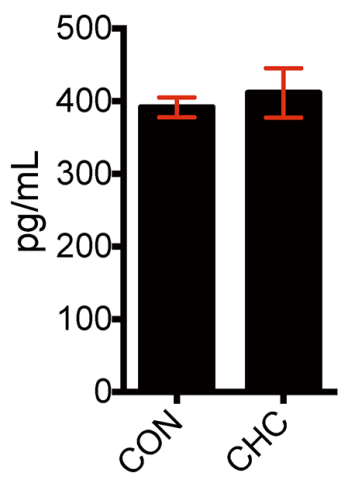

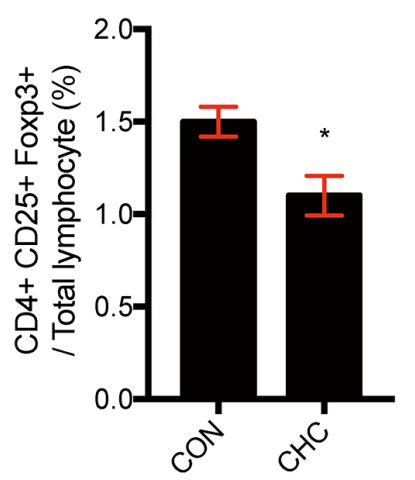

E.
B.

Lymph Node

F.

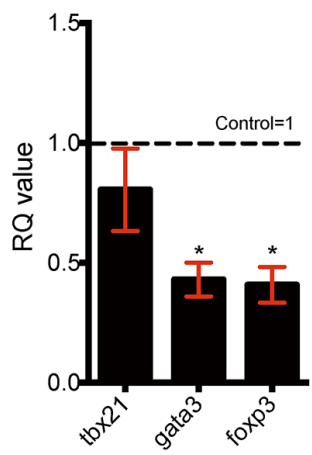

IL-17
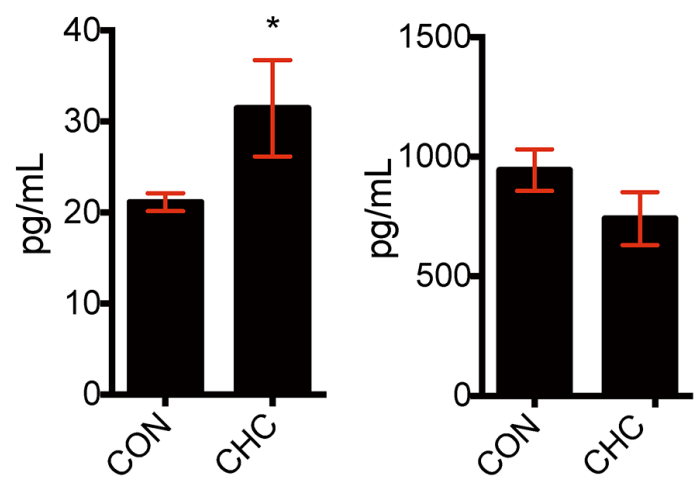

I.

J.

IFN- $\gamma$

Angiotensin II
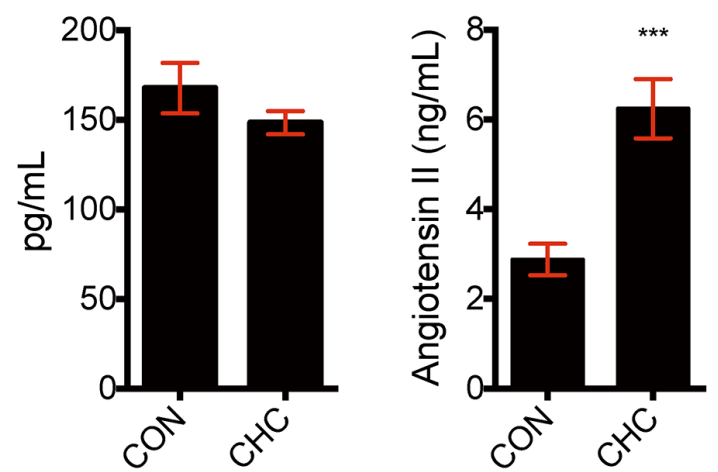

Figure 2: CHC-induced depressive-like behavior is associated with altered peripheral immune system. Mice were administrated with $\mathrm{CHC}(40 \mathrm{mg} / \mathrm{kg} / 21$ days or more). Following the termination of $\mathrm{CHC}$ treatment, spleens of mice were analyzed with flow cytometry and expressed with percentage of CD4+CD25+Foxp3 + cells to total lymphocytes (A) and $n=3$ in each group. Mesenteric lymph nodes of mice were also dissected for quantitative reverse transcriptase polymerase chain reactions(qPCR) to assess transcription factors of T Helper 1 cells (tbx21), T Helper 2 cells (gata3) and regulatory T cells (foxp3) (B). $n=8-15$ in each group. Serums of CHC mice and the controls were obtained to measure pro- and anti-inflammatory cytokines, such as TNF- $\alpha$ (C), IL-1 $\beta$ (D), IL-6 (E), IL-17 (F), IL-4 (G), IL-10 (H), IFN-y (I), using Bio-Rad Bio-Plex® assay and circulating levels of angiotensin II (J) by Enzyme Immunoassay (EIA). $\mathrm{n}=8-10$ in each group. The data shown are mean \pm SEM.* $\mathrm{p}<0.05,{ }^{* * *} \mathrm{p}<0.001$ compared with the controls. 


\section{CHC did not affect serotonin system and HPA axis in brain of mice}

To verify the effect of $\mathrm{CHC}$ on other pathways related to depression, factors associated with monoamine system and HPA axis in brain were assessed. Serotonin (5HT) and its main metabolite, 5-hydroxyindoleacetic acid (5-HIAA) were measured in the hippocampus by HPLC and showed no change in CHC mice (Figure 4A, 4B). In addition, $\mathrm{CHC}$ did not affect to $\mathrm{CRH}$ mRNA expression in the hypothalamus and serum glucocorticoid level (Figure 4C, 4D).

\section{DISCUSSION}

In this study, CHC $(40 \mathrm{mg} / \mathrm{kg} / \mathrm{day} * 21$ days $)$ treated mice exhibited depression-like behaviors in only TST and FST, but not SP. Moreover, CHC did not affect anxiety and sociality. However, imipramine or captopril discontinuation rescued $\mathrm{CHC}$-induced depressive-like behaviors in TST and FST. Although CHC mice exhibited less weight gain compared to the controls, it did not seem to be due to systemic illness because $\mathrm{CHC}$ increased glycerol release and lipid metabolism [35]. In addition, CHC did not affect to serum GOT level and motor activity. Therefore, we concluded that $\mathrm{CHC}$ might have distinct pathomechanism from other depression models [40, 41].

Our data suggest that depressive-like behavior induced by $\mathrm{CHC}$ are associated with alteration of the peripheral immune system, including elevations of pro-inflammatory cytokines such as IL-1 $\beta$ and IL-6, with Treg and Th2 reduction. Treg reduction induces pro-inflammatory cytokines elevation [42], which can suppress inducible Treg development, and results in a vicious cycle $[43,44]$. Consistent with the alteration in the peripheral cytokine profiles, mRNA expressions of gata3 (Th2 transcription factor) and foxp3 (Treg transcription factor) were decreased in the mesenteric lymph nodes in the $\mathrm{CHC}$ mice. These data propose that $\mathrm{CHC}$ reduce Treg population and this immunologic change might elevate the peripheral pro-inflammatory cytokines.

Many investigators have suggested a correlation between peripheral cytokines and depression [15, 45]. A meta-analysis reports significantly higher concentrations of the pro-inflammatory cytokines, such as TNF- $\alpha$ and IL-6, in blood of depressed subjects [36]. CHC also increased serum IL-1 $\beta$ and IL-6 level. Assuming that this peripheral immunologic change may have an influence on brain inflammation $[19,28]$, we found that mRNA expressions of pro-inflammatory cytokines, such as TNF- $\alpha$ and IL- 6 , were increased in the hippocampus of $\mathrm{CHC}$ mice. These changes were rescued by imipramine. This result is also supported by the previous study that reported that imipramine decreased pro-inflammatory cytokines in microglial cells [46]. Captopril-treated BV-2 cells, murine microglia cell line, did not exhibit significant changes in pro-inflammatory cytokines (data not shown) and these changes in pro-inflammatory cytokines in the hippocampus may not be a direct effect of captopril on microglia. In contrast with serum level, hippocampal mRNA expression level of IL- $1 \beta$ was not changed in CHC mice. Based on the report that chronic stress can elevate IL-6 level in the absence of elevations of IL- $1 \beta$ in the cortex [47], it seems to be possible that $\mathrm{CHC}$ can elevate both TNF- $\alpha$ and IL- 6 mRNA without IL- $1 \beta$ among proinflammatory cytokines in the hippocampus of $\mathrm{CHC}$ mice.

Considering that microglia can release proinflammatory cytokines, the increased number and ramifications of microglia may be associated with elevation of TNF- $\alpha$ and IL-6 mRNA expressions in the hippocampus [21]. In consistent with many papers suggesting association between inflammatory microglia and depression [15], inflammatory microglia might be a critical role in depressive-like behaviors in $\mathrm{CHC}$ mice. In addition, inflammatory microglia with TNF- $\alpha$ and IL-6 increase might contribute to reduction of GR expression in the hippocampus, leading to glucocorticoid resistance, which is observed in depressed patient [39]. Van Bogaert et al.[48] suggested that reduced GR levels by TNF- $\alpha$ may not be dependent on increased corticosterone production. However, CHC did not affect CX3CR1 and CD200r mRNA expressions in the hippocampus, which were known as anti-inflammatory functional markers of microglia related with stress vulnerability $[19,49]$.

Hypothalamic-Pituitary-Adrenal (HPA) axis activation is exhibited in many depression animal models and hypothalamus, a constituent of HPA axis, is one of brain areas that is often examined in depression studies. Contrary to the hippocampus, $\mathrm{CHC}$ did not induce inflammatory reaction in the hypothalamus. Although we could not explain exactly the region-specific inflammatory reaction in $\mathrm{CHC}$ mice, it might be related with fact that hippocampus is known to be one of the most vulnerable area to stressful stimuli in brain because of its high plasticity [50]. However, further study will be required to clarify the mechanism of $\mathrm{CHC}$.

Our result showed that $\mathrm{CHC}$-mice did not affect depression-associated factors such as BDNF, serotonin, and KYN pathway. BDNF, serotonin receptors, and IDO have been suggested as main targets of antidepressant studies [51]. However, we did not observe any significant change in mRNA expressions of BDNF, IDO, KAT, and $\mathrm{KMO}$ in the hippocampus of $\mathrm{CHC}$ mice, while they exhibited depressive-like behavior. Moreover, CHC did not induce significant change in 5-HT and HIAA concentration and expressions of serotonergic receptors in the hippocampus of mice. Furthermore, CRH mRNA expression in the hypothalamus and serum corticosteroid level was not altered in $\mathrm{CHC}$ mice despite reduction of hippocampal GR expression mentioned above. Thus, $\mathrm{CHC}$ seems to induce depressive-like behaviors through a possible alternative pathway instead of well-known 
A.

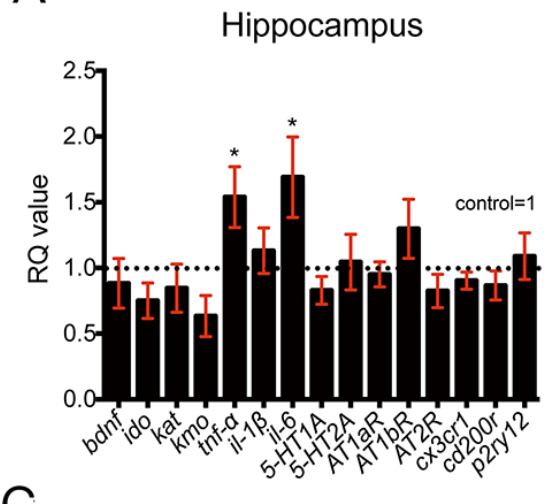

C.

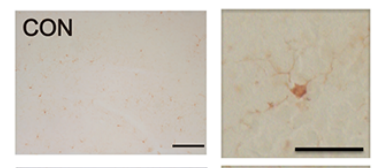

$\mathrm{CHC}$

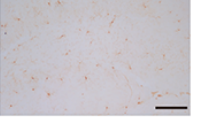

$\mathrm{Co}-\mathrm{Imi}+\mathrm{CHC}$

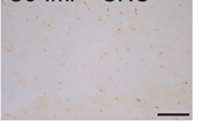

E.

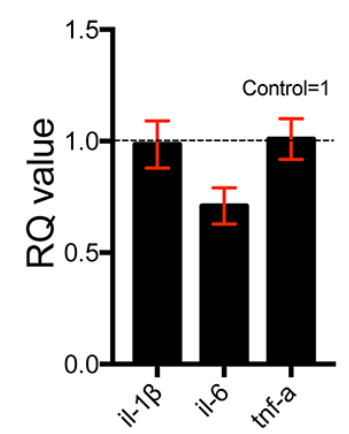

$\mathrm{F}$.
B.

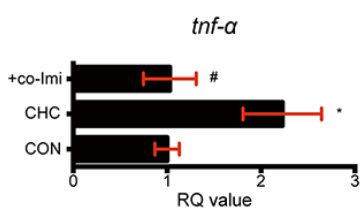

il-6

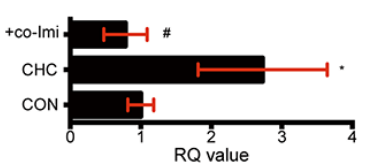

D.
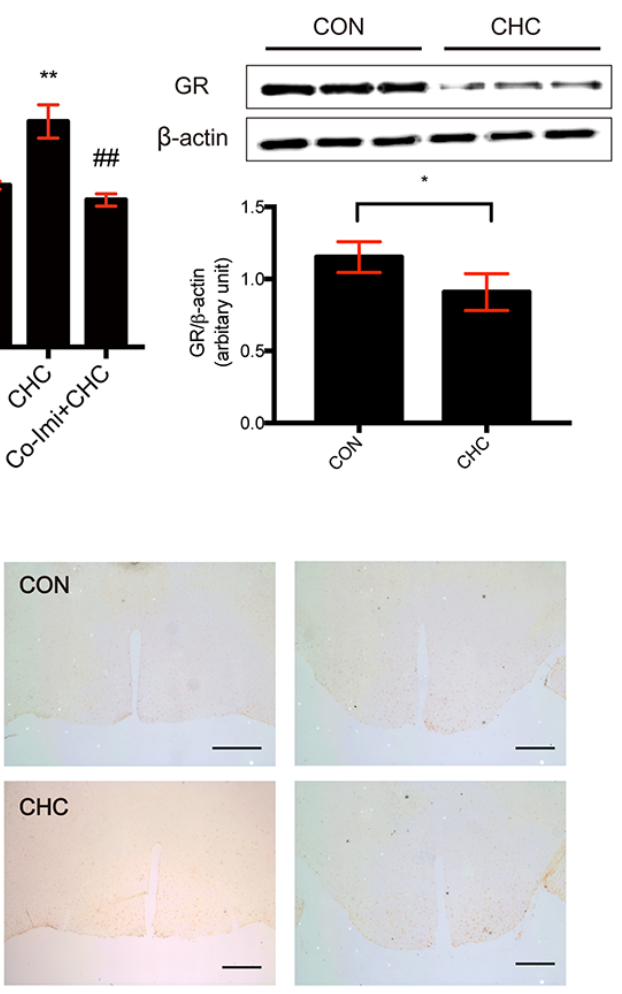

Figure 3: CHC increased inflammatory reaction in the hippocampus but not in the hypothalamus. Several markers involved in depression (bdnf, ido, kat, kmo), pro-inflammatory cytokines (tnf- $\alpha$, il-1 $\beta$, and il-6), serotonin receptors (5-HT1A and 5-HT2A), angiotensin receptors (AT1bR, AT1bR, and AT2R), and microglial phenotype (cx3cr1, cd200r, and p2ry12) were examined in the hippocampus (A) and $\mathrm{n}=7-12$ in each group. The mRNA expression levels of TNF- $\alpha$ and IL-6 (B) were measured by qPCR to identify the effect of imipramine co-treatment (Co-Imi). The CT values were normalized as a ratio as controls being 1 and RQ value refers to the ratio of respective transcription factors as a percentage of the controls. $\mathrm{n}=7-12$ in each group. An immunohistochemical study was performed to determine Iba-1 immunoreactivity in the hippocampus (C) in $20 \mathrm{X}$ (left), $40 \mathrm{X}$ (right) images and cells that are immunoreactive to Iba-1 were counted in same regions of dentate gyrus. $\mathrm{n}=10-15$ in each group. Scale bar $=100 \mu \mathrm{m}$. GR levels of the hippocampus (D) were assessed by western blot analysis and expression of GR was quantified using Image $J . n=5$ in each group. The mRNA expressions of immunologic markers (E) such as IL-1 $\beta$, IL-6, TNF- $\alpha$ in the hypothalamus were measured by qPCR. The CT values were normalized as a ratio as controls being 1 and RQ value refers to the ratio of respective transcription factors as a percentage of the controls. $n=5$ in each group. Iba-1 immunoreactivity was also assessed in the hypothalamus $(\mathbf{F})$ in $4 \mathrm{X}$ images. The images were taken from bregma level $-0.46 \mathrm{~mm}$ (left) and bregma level $-2.06 \mathrm{~mm}$ (right). $\mathrm{n}=10-15$ in each group and shown images are representative images. Scale bar $=50 \mu \mathrm{m} .{ }^{*} \mathrm{p}<0.05,{ }^{* *} \mathrm{p}<0.01$ compared with the controls. $\# \mathrm{p}<0.05, \# \# \mathrm{p}<0.01$ compared with the CHC- treated groups. 
mechanisms including serotonergic pathway, HPA axis activation, or KYN pathway.

Notably, we observed increased level of ANG II in $\mathrm{CHC}$ mice despite the chronic high-dose captopril administration. Captopril is known to decrease blood pressure by reducing synthesis of ANG II from ANG I by inhibiting ACE. This contradictory result can be explained by a possibility that chronic ACE inhibition by $\mathrm{CHC}$ may have activated the compensative ACE or chymase, an enzyme that performs the same function as ACE (43). However, CHC did not affect to heart chymase and lung ACE mRNA level (data not shown). Thus, it can be speculated that RAAS system including ACE and ANG II may not be as simple as we have known (37-42). Considering this complexity of RAAS system, it is difficult to elucidate underlying mechanism clearly, which is a limitation of this study.

A.

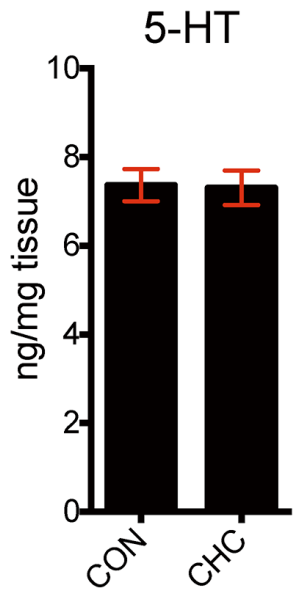

C.

Hypothalamus crh

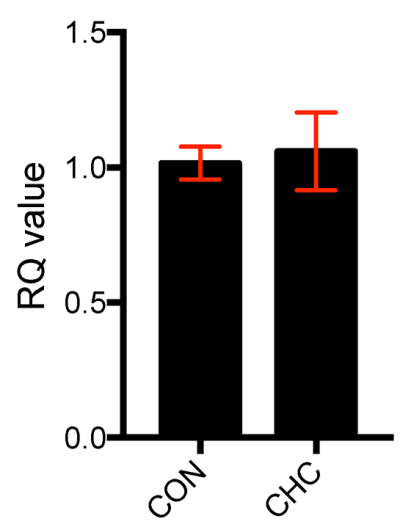

Interestingly, imipramine did not rescue peripheral ANG II elevation and Treg reduction in $\mathrm{CHC}$ mice (data not shown), while imipramine restored increased TNF- $\alpha$ and IL- 6 in the hippocampus and depressivelike behavior induced by $\mathrm{CHC}$ treatment. Based on the results, ACE and ANG II may be hidden depression recurrence-related factors that may not be affected by traditional antidepressants, even though we could not determine a direct link between the ANG II and depression recurrence. Although we could not determine whether chronic ANG II elevation itself can induce depressive-like behaviors, previous papers have mentioned mood-elevating effect in therapeutic dose of captopril and suggested the association between ANG II and depression [59]. Similarly, CHC induced depressivelike behavior in mice with serum ANG II elevation in our data. Endogenous ANG II increased T-cell activation,

B.

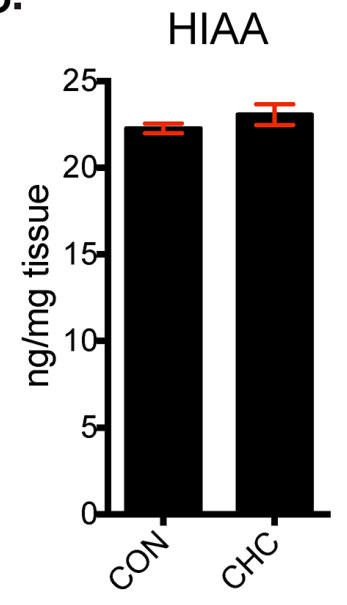

D.

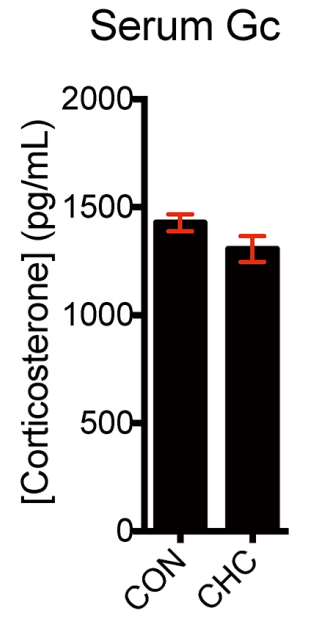

Figure 4: CHC did not affect monoamine system and HPA axis in brain of mice. The levels of serotonin (5-hydroxytryptamine, 5-HT) (A) and hydroxyindoleacetic acid (HIAA) (B) were measured in hippocampus tissue of mice and $\mathrm{n}=5$ in each group. The mRNA expressions of $\mathrm{CRH}$ (corticotropin-releasing hormone) in the hypothalamus (C) were assessed by qPCR and $\mathrm{n}=5$ in each group. Serum glucocorticoid levels (D) were measured by EIA assay and $n=5$ in each group. Data shown are mean \pm SEM. 
Table 1: Primer information

\begin{tabular}{|c|c|c|c|}
\hline Primer & Forward $\left(5^{\prime} \rightarrow 3^{\prime}\right)$ & Reverse $\left(5^{\prime} \rightarrow 3^{\prime}\right)$ & PCR product(bp) \\
\hline Tbx21 & CAACAACCCCTTTGCCAAAG & TCCCCCAAGCAGTTGACAGT & $108 \mathrm{bp}$ \\
\hline Gata3 & AGAACCGGCCCCTTATCAA & AGTTCGCGCAGGATGTCC & 71 \\
\hline Foxp3 & GAACCCAATGCCCAACCCTAG & TTCTTGGTTTTGAGGTCAAGGG & 1311 \\
\hline BDNF & TGCAGGGGCATAGACAAAAGG & CTTATGAATCGCCAGCCAATTCTC & 109 \\
\hline IDO & TGTGAATGGTCTGGTCTC & CTGTGCCCTGATAGAAGT & 238 \\
\hline KAT & GTTCTCCACACACAAGTCTC & GGATCCATCCTGTCAGTCA & 524 \\
\hline KMO & GGTCGCCTTCACCAGAATAA & ATCCAGGCAGGTCTTCTCAA & 176 \\
\hline TNF- $\alpha$ & GAGTCCGGGCAGGTCTACTTT & CAGGTCACTGTCCCAGCATCT & 234 \\
\hline $\mathrm{IL}-1 \beta$ & GGCTGGACTGTTTCTAATGC & ATGGTTTCTTGTGACCCTGA & 133 \\
\hline IL-6 & CCACTTCACAAGTCGGAGGCTTA & GCAAGTGCATCATCGTTGTTCATAC & $111 / 172$ \\
\hline 5-HT1A & CTGTTTATCGCCCTGGATG & ATGAGCCAAGTGAGCGAGAT & 157 \\
\hline 5-HT2A & CCGCTTCAACTCCAGAACCAAAGC & CTTCGAATCATCCTGTACCCGAA & 108 \\
\hline AT1aR & GGACACTGCCATGCCCATAAC & TGAGTGCGACTTGGCCTTTG & 144 \\
\hline AT1bR & CTGCTATGCCCATCACCATCTG & GATAACCCTGCATGCGACCTG & 147 \\
\hline AT2R & GCACCAATGAGTCCGC & AGGGAGGGTAGCCAAA & 214 \\
\hline Cx3cr1 & TGGCCCAGCAAGCATAG & CATGTCTGCTACCCTCACAAA & 93 \\
\hline $\mathrm{Cd} 200 \mathrm{r}$ & AAATGCAAATTGCCAAAATTAGA & GTATAGCTAGCATAAGGCTGCATTT & 73 \\
\hline P2ry12 & GGGCGTACCCTACAGAAACA & TGTTGACACCAGGCACATCC & 204 \\
\hline $\mathrm{CRH}$ & GTTAGCTCAGCAAGCTCACAG & GCCAAGCGCAACATTTCATTT & 69 \\
\hline
\end{tabular}

leading to production of TNF- $\alpha$ [60] and blocking of ACE was found to increase Treg population in the spleen [61]. Additionally, ANG II increased IL-6 release in monocytes [62] and the increased IL-6 in CHC mice might affect to Treg population in $\mathrm{CHC}$ mice. It has been reported that IL-6 was required for overcoming Treg suppressive function with some other cytokines [63]. Likewise, trans-signaling via the soluble IL-6 receptor abrogates the induction of Foxp3 and the generation of Treg in naïve CD4 T cells through upregulation of the TGF $\beta$ signaling inhibitor $\operatorname{Smad} 7$ [64]. IL-1 $\beta$, as well as IL-6, is known to modulate the activation of STAT transcription factors, thereby inhibiting FoxP mRNA expression and regulating the balance of Th17 and Treg cells [43]. These findings suggest that ANG II, IL-6, and IL-1 $\beta$ might be involved independently or together in reduction of Treg population. However, considering the existence of ANG II receptor in brain [59] and ability of ANG II to activate microglia and induce inflammation [65-67], it should not be excluded that increased serum ANG II by CHC may have a direct effect on alteration of mice behavior, although ANG II receptors was not changed in the hippocampus. Additionally, we cannot exclude the possibility of captopril crossing the bloodbrain barrier to have a direct effect on the brain of mice through ACE or renin-angiotensin system within the brain, although captopril did not affect to mRNA level of inflammatory cytokines in BV2 cell line (data not shown). Thus, our results might be translated to explain the comorbidity with cardiovascular disease and depression [68].

In summary, we found that $\mathrm{CHC}$ induced a decrease in Treg population and alterations in peripheral proinflammatory cytokines. These changes in the peripheral immune condition might have affected the CNS, especially the hippocampus, including microglial status and expressions of pro-inflammatory cytokines, and they altogether may have led to depressive-like behavior in mice. However, $\mathrm{CHC}$ did not affect serotonin level in the hippocampus, KYN pathway, and HPA axis activation, which are well-known depressionrelated pathways. Thus, $\mathrm{CHC}$ may propose a novel alternative mechanism in depression pathogenesis.

\section{MATERIALS AND METHODS}

\section{Experimental animals}

Male C57BL/6 mice at age of 7 weeks (Orient Bio Inc. Seoul, Korea) weighing 20-25 g were used 
for all the experiments. Animals were housed five per cage in a room maintained at $22 \pm 0.5^{\circ} \mathrm{C}$ with an alternating 12-h light-dark cycle. Food and water were available ad libitum. Animals were allowed to acclimate to the laboratory for a week before the beginning of the experiments. To reduce variation, all experiments were performed during the light phase of the cycle. All experimental procedures were approved by the Animal Care and Use Committee of the CHA University (IACUC130018 and IACUC130025).

\section{Captopril and drug treatment}

Mice were randomly assigned to controls or experimental groups. For restraint stress, the mice were forced into $50 \mathrm{~mL}$ Corning tubes with a nose-hole for ventilation, $2 \mathrm{~h}$ per day (11:00 AM-1:00 PM). The mice were exposed to restraint stress $(2 \mathrm{~h}$ /day) for 21 consecutive days and this procedure is referred to as chronic restraint stress (CRS). CRS group was added as a positive control. To determine dose-dependent effect of captopril administration, captopril (Sigma-Aldrich, St. Louis, Missouri) was administered by dissolving in their drinking water at concentration of 25 or $40 \mathrm{mg} / \mathrm{kg} /$ day. To examine time-course effect of captopril, 40 $\mathrm{mg} / \mathrm{kg}$ of captopril was administered in their drinking water for 7 days, 14 days and 21 days. The daily drinking volume of control mouse was $4.216 \pm 0.1375 \mathrm{ml}$ and that of $\mathrm{CHC}$ mice was $3.92 \pm 0.1013 \mathrm{ml}$. There was no significant difference in daily drinking volume between control and CHC-mice.

Experiment 1: Following the examination of both dose-dependent effect and time-course effect of captopril, chronic high-dose captopril (CHC) was defined as 40 $\mathrm{mg} / \mathrm{kg} /$ day of captopril treatment for 21 days or more, and captopril treatment was continued during period for behavior assessment (Supplementary Figure 1A).

Experiment 2: In order to evaluate the effect of captopril washout, captopril in drinking water was removed and regular drinking water was given for 7 days after the termination of 21 day of captopril treatment (Supplementary Figure 1B).

Experiment 3: To assess antidepressant effect of imipramine co-treatment (Co-Imi), imipramine (SigmaAldrich, St. Louis, Missouri; $20 \mathrm{mg} / \mathrm{kg}$ ) was dissolved in physiologic normal saline and treated intraperitoneally once a day during captopril administration (Supplementary Figure 1C).

Experiment 4: In order to assess antidepressant effect of imipramine after induction of depressionlike behavior by $\mathrm{CHC}$, imipramine was treated for 14 days with additional captopril after 21 days of captopril treatment (post-Imi) (Supplementary Figure 1D).

\section{Behavioral testing}

Behavior testing was performed referring to our previous studies $[19,33]$. Mice were allowed to acclimate to a testing room for at least 30 min before performing the experiments. All experiments were conducted during the light cycle between 9:00 AM and 4:00 PM in a series, one experiment per day. Light-dark exploration (LD), elevated plus maze (EPM) and SI were done using EthoVision XT9 video tracking system (EthoVision ${ }^{\circledR}$ Version 9, Noldus, Netherlands). Tail suspension test (TST) and forced swimming test (FST) were conducted by two observers to minimize error.

Rotarod test: Locomotor activity of mice was assessed using a rotarod system (Rota Rod-R V2.0, B.S Technolab INC). Before measuring, mice were adapted to the rod with a constant speed of $4 \mathrm{rpm}$ for 3 minutes. Mice were conditioned on the rod (diameter: $3.5 \mathrm{~cm}$ ) with an increasing speed of 4 to $40 \mathrm{rpm}$ (accelerated by $1 \mathrm{rpm}$ per $5 \mathrm{~s}$ ). Motor ability was measured as the time until the mouse falls off the rod, up to $300 \mathrm{~s}$. The average latency time of 3 trials was calculated for statistical analyses. The interval period between trials was $20 \mathrm{~min}$.

Sucrose preference test (SP): Preference for sucrose solution over drinking water was measured to assess anhedonia, which is usually decreased in depressed mice as same as previous paper [19]. To assess SP, mice were provided with two bottles filled with $1 \%$ sucrose diluted in drinking water or drinking water alone. Animals were acclimatized to two bottle conditions for two consecutive days and were tested for their choice for two additional days. The position of the bottles was interchanged during 4 days of testing. On each test day, the fluid levels were noted. SP was calculated as percentage of sucrose/total fluid consumed.

Light-dark exploration (LD): Anxiety-like behavior was measured using EPM and LD by assessing their tendency to avoid bright light and open spaces. The apparatus used in this assessment was a box $(30 \times 30 \times 30$ $\mathrm{cm})$ consisting of one brightly lit open chamber connected to a darkened enclosed chamber. The chambers were connected by a small square hole $(7 \times 7 \mathrm{~cm})$. Mice were placed in the corner of the lit chamber, facing away from the dark chamber, and the number of transitions between the chambers and time spent in the dark chamber were manually measured for $10 \mathrm{~min}$.

Elevated plus maze (EPM): EPM apparatus and procedure were modified as our previous paper [19]. The apparatus consisted of four open roof arms $(30 \times 5 \mathrm{~cm})$ made of white matte plexiglass. The two opposite arms were enclosed with 20-cm-high walls (closed arms), and the remaining two opposite arms had no walls (open arms). The four arms were placed at $90^{\circ}$ to each other around a $5 \times 5-\mathrm{cm}$ square in the center. The apparatus was elevated $30 \mathrm{~cm}$ above the floor. The mouse was initially placed in the center of the apparatus, facing one of the open arms away from an experimenter, and allowed to explore the apparatus freely for $5 \mathrm{~min}$. The number of entries to open 
arms and closed arms was recorded, and the times spent in each arm were recorded using EthoVision XT9 video tracking system.

Tail suspension test (TST): The apparatus consisted of a cupboard with a hook attached to the top. The mice were suspended by securing the tail to the hook by wrapping adhesive tape around the tail. The tail was suspended carefully not to fold the tail, and the tip of the tail was wrapped $2 \mathrm{~cm}$ away from the top of the hook. The data of the mice that climbed their tails were removed from the test. The time spent immobile during a 7-min testing period was measured. The observers were blinded to the groups. The time spent immobile was measured and compared by two observers to minimize the bias.

Forced swimming test (FST): In FST, we assessed the ability of mice to cope with an inescapable stressful situation, which reflects depressive-like behavior. Mice were individually placed in a $2 \mathrm{~L}$ Pyrex beaker $(13 \mathrm{~cm}$ diameter, $24 \mathrm{~cm}$ height), filled with $23{ }^{\circ} \mathrm{C}$ water with a depth of $17 \mathrm{~cm}$. All mice were forced to swim for $6 \mathrm{~min}$, and the duration of immobility was measured during the final 5 min of the test. The immobility was defined as the time that the mouse spent floating without struggling and making only the movements necessary to keep its head above the water level. The observers were blinded to the groups. The time spent immobile was measured and compared by two observers to minimize the bias.

Social interaction (SI): Social interaction was performed as previously described [34]. In trial 1 (Empty), mice were placed into the arena with empty wire mesh cage at one end. Their movement was monitored for $2.5 \mathrm{~min}$ in the absence of a mouse. In trial 2 (Social), an unfamiliar mouse was placed in the wire mesh cage and the experimental mouse was placed in the arena, and activity was recorded for $2.5 \mathrm{~min}$. Activity in the social avoidance behavior test was video recorded and analyzed using EthoVision XT9 video tracking system.

\section{Flow cytometry analysis}

Spleen was digested with collagenase IV (SigmaAldrich, St.Louis, MO) and DNase I (Sigma-Aldrich) in RPMI medium (Gibco, Carlsbad, CA) for $30 \mathrm{~min}$ at 37 ${ }^{\circ} \mathrm{C}$, and filtered through $40 \mu \mathrm{m}$ Gauze (BD Biosciences, San Jose, CA) to generate single cell suspension. Cells were fixed, permeabilized, and stained mouse regulatory T cell staining kit (eBioscience, San Diego, CA, 88-8118$40)$. The regulatory $\mathrm{T}$ cell were measured and analyzed according to the manufacturer's instruction. Briefly, 5 $\times 10^{6} / \mathrm{mL}$ of cells were immunolabeled using antibodies against surface proteins CD4, CD25, and intracellular protein FoxP3. Briefly, cells were incubated in CD4-FITC and CD25- PE or isotype-matched control antibodies for $20 \mathrm{~min}$ at $20-23.5^{\circ} \mathrm{C}$ in the dark; the cells were then washed with $1 \mathrm{~mL}$ staining buffer and fixed with the fixation buffer that was supplied in mouse regulatory $\mathrm{T}$ cell staining kit for $10 \mathrm{~min}$ at $20-23.5^{\circ} \mathrm{C}$ in the dark. The cells were permeabilized using permeabilization buffer for $1 \mathrm{~h}$ at $20-23.5^{\circ} \mathrm{C}$ and then washed with $1 \mathrm{~mL}$ of staining buffer. After washing, the cells were incubated in APCconjugated anti-mouse FoxP3 or the isotype control for at least $30 \mathrm{~min}$ at $20-23.5^{\circ} \mathrm{C}$ in the dark. At the end of the incubation period, cells were washed and resuspended in staining buffer. Data acquisition was performed with BD FACS Calibur and data were analyzed with FlowJo software (Treestar Inc., Ashland, OR).

\section{Quantitative reverse transcriptase polymerase chain reaction (qRT-PCR)}

The hippocampus, hypothalamus and the mesenteric lymph nodes were dissected after captopril administration for 21 days followed by series of behavioral test. For RNA extraction, the frozen tissue was homogenized in $1 \mathrm{~mL}$ of QIAzol reagent per $100 \mathrm{mg}$ of tissue (Qiagen, Valencia, CA). Chloroform was added to separate the phase that contains RNA, and isopropyl alcohol was added to precipitate RNA. The precipitated RNA pellet was redissolved in DEPC- treated water (Bioneer, Seongnam, Korea) after air-drying the pellet. Quantification of RNA concentration was determined by the absorption at 260 $\mathrm{nm}$. One microgram of messenger RNA (mRNA) was reverse-transcribed into cDNA in $20 \mu \mathrm{L}$ of reaction mix using RevertAid First Strand cDNA Synthesis kit (Thermo scientific). Quantitative PCR was performed using Power SYBR ${ }^{\circledR}$ Green PCR Master Mix (Life technologies, Warrington, UK). Primer sequences are listed in Table 1. The cyclic conditions consisted of an initial enzyme activation at $95{ }^{\circ} \mathrm{C}$ for $5 \mathrm{~min}$ followed by 40 cycles of denaturation at $95{ }^{\circ} \mathrm{C}$ for $20 \mathrm{~s}$, annealing, and extension including detection of SYBR Green bound to PCR product at $56{ }^{\circ} \mathrm{C}$ for $40 \mathrm{~s}$. Glyceraldehyde 3-phosphate dehydrogenase (GAPDH) was used as an internal control for normalization. The relative quantities of PCR fragments were calculated using the comparative CT method.

\section{Immunohistochemistry}

For perfusion, mice were sacrificed after $\mathrm{CHC}$ treatment. All mice were first deeply anesthetized with pentobarbital $(100 \mathrm{mg} / \mathrm{kg}$, i.p.), and perfused through the heart with physiological saline followed with icecold phosphate-buffered 4\% paraformaldehyde $(\mathrm{pH}$ 7.4). Whole brain was dissected and post-fixed in the same fixative for $4 \mathrm{hr}$ at $4^{\circ} \mathrm{C}$. Then the brain blocks were cryoprotected in $30 \%$ sucrose for $24 \mathrm{hr}$ at $4{ }^{\circ} \mathrm{C}$. Sections were cut with an electronic cryotome at a thickness of $25 \mathrm{~mm}$. Immunohistochemical staining was performed with the Elite ABC Kit (Vector Laboratories). Sections were first rinsed with $0.1 \mathrm{M}$ bovine serum albumin three times for $10 \mathrm{~min}$ each, then pre-incubated in $0.1 \mathrm{M}$ PBS containing $1 \%$ bovine serum albumin and $0.2 \%$ Triton 
X-100 for $30 \mathrm{~min}$. After rinsing twice with $0.1 \mathrm{M}$ PBS containing $0.5 \%$ BSA for 10 - 15 min each, sections were incubated with anti-Iba-1 antibody (1:300; Wako, Cat. \# 019-19741) diluted with 0.1 M PBS containing 0.5\% BSA and $0.05 \%$ sodium azide at $4{ }^{\circ} \mathrm{C}$. After overnight incubation, sections were rinsed and incubated with biotinylated anti-rabbit IgG secondary antibody (Vector) 1:200 diluted with 0.1 M PBS containing 0.5\% BSA for $1 \mathrm{hr}$ at room temperature. After rinsing, the sections were incubated with $\mathrm{ABC}$ reagent 1:200 diluted with PBS for $1 \mathrm{hr}$ at room temperature and then rinsed with PBS followed with $0.1 \mathrm{M}$ phosphate buffer. Finally, sections were incubated in SIGMA FAST DAB kit (Sigma) until the desired stain intensity developed. Sections were rinsed with $0.05 \mathrm{~mol} / \mathrm{L}$ phosphate buffer, and then the sections were dehydrated through graded ethanols, cleared in histoclear (Fisher), and cover slipped using Permount (Fisher). Histological analysis was performed using the following procedure, which is modified from the previous studies [33, 69]. The number of Iba-1-positive neurons in the hippocampus was counted in three sections for each mouse. Starting from the first section (interaural $2.10 \mathrm{~mm}$, bregma $-1.70 \mathrm{~mm}$ ), counts were taken from three coronal sections at $0.135 \mathrm{~mm}$ increments. The number of cells that are immunoreactive to Iba-1 was counted by two blinded observers using a microscope in the same brain area (Nikon). For images of hypothalamus, sections were taken from the level of interaural $3.34 \mathrm{~mm}$, bregma -0.46 $\mathrm{mm}$ to the level of interaural $1.50 \mathrm{~mm}$, bregma $-2.30 \mathrm{~mm}$ at $0.135 \mathrm{~mm}$ increments.

\section{Total protein extraction and western blot analysis}

Hippocampal protein was extracted and expression levels were assessed using Western blotting. After dissecting the hippocampus, the tissue was washed two times with cold Tris-buffered saline (TBS; 20-mM Trizma base and $137 \mathrm{mM} \mathrm{NaCl}, \mathrm{pH}$ 7.5). Immediately after washing, tissue was lysed with SDS lysis buffer $(62.5 \mathrm{mM}$ Trizma base, $2 \% \mathrm{w} / \mathrm{v}$ SDS, $10 \%$ glycerol) containing $0.1 \mathrm{mM} \mathrm{Na} 3 \mathrm{VO} 4,3 \mathrm{mg} / \mathrm{ml}$ aprotinin, and $20 \mathrm{mM} \mathrm{NaF}$. After brief sonication to shear DNA and reduce viscosity, protein concentration was determined with a detergentcompatible protein assay reagent (Bio-Rad Laboratories) using bovine serum albumin as the standard. After adding dithiothreitol $(5 \mathrm{mM})$ and bromophenol blue $(0.1 \% \mathrm{w} / \mathrm{v})$, the proteins were boiled, separated by electrophoresis in 10 $\%$ polyacrylamide gels (Invitrogen), and transferred onto a polyvinylidene difluoride (PVDF) membrane (Bio-Rad Laboratories). Membranes were blocked on a shaker for 1 $\mathrm{h}$ at room temperature. Blocking buffer consisted of TBST (Tris-buffered saline/0.1\% Tween-20) and $5 \%$ skim milk. Primary antibodies were dissolved in the blocking buffer and the membranes were immunoblotted with antibodies against glucocorticoid receptor (GR; 1:1000, Santa cruz,
Sc-1004) and beta-actin (1:1000, Cell Signaling, 4970) for overnight at $4^{\circ} \mathrm{C}$. The membranes were incubated in the anti-rabbit (1:2000, Cell Signaling, 7074) dissolved in the blocking buffer at a room temperature for $80 \mathrm{~min}$. The membranes were visualized with ECL-plus solution (Amersham Pharmacia Biotech). Then, the membranes were then exposed to chemiluminescence (LAS- 4000, Fujifilm) for detection of light emission. Western blot results were quantified using ImageJ 1.51 software (National Institutes of Health, Bethesda, MD) after densitometric scanning of the films.

\section{Quantification of serotonin}

(5-hydroxytryptamine, 5-HT) and its metabolite, 5- hydroxyindoleacetic acid (5-HIAA) by high pressure liquid chromatography and electrochemical detection (HPLC-ECD)

Mice were immediately sacrificed after captopril administration for 21 days followed by series of behavioral test. Brain tissue blocks were rapidly dissected in ice and homogenized with ice-cold $0.4 \mathrm{M}$ perchloric acid, then incubated on ice for $1 \mathrm{~h}$. After centrifugation at 21,130 $\mathrm{g}$ for $30 \mathrm{~min}$ at $4^{\circ} \mathrm{C}$, the supernatant was filtered using an appropriate column (\#Sc1000-1Kt, SigmaPrep spin column). Filtered supernatants were directly injected onto the Nova-Pak C18 reversed-phase column. The mobile phase consisted of $0.1 \mathrm{M}$ sodium phosphate monobasic, 0.1mM EDTA, $1 \mathrm{mM}$ sodium octyl sulfate, $0.003 \%$ trimethylamine, and $10 \%$ methanol at $\mathrm{pH} 3.7$. The external standard solutions for each analyte were 5-hydroxytryptamine (5-HT; sc-298707, Santa Cruz) and 5-hydroxyindole-3-acetic acid (5-HIAA; \#H8876, Sigma-Aldrich) solutions in HPLC grade water with $0.4 \mathrm{M}$ perchloric acid. The flow rate was kept constant at $1 \mathrm{ml} /$ min. Chromatographic peak analysis was accompanied by identification of unknown peaks in a sample matched according to retention times.

\section{Determination of serum chemistries}

Mice were sacrificed after captopril administration for 21 days followed by series of behavioral test and whole blood was collected by cardiac puncture. The serum was isolated and stored at $-80{ }^{\circ} \mathrm{C}$ until assayed.

Serum oxaloacetic transaminase (GOT) level was measured by Reitman-Frankel method with GOT kit according to manufacturer's instruction (Asan pharmaceutical, Seoul, Korea).

Serum cytokine (TNF- $\alpha$, IL-1 $\beta$, IL-6, IL-17, IL-4, IL-10 and IFN- $\gamma$ ) levels were measured using Bio-Rad Bio-Plex ${ }^{\circledR}$ assay (Bio-Rad, Hercules, CA). The cytokine levels were measured and analyzed according to the manufacturer's instruction.

Serum angiotensin II (ANG II) level was measured by angiotensin II EIA kit according to manufacturer's 
instructions (Pheonix Pharmaceuticals, Burlingame, CA, USA).

Serum corticosterone level was determined by corticosterone EIA kit according to manufacturer's instructions (Cayman Chemical, Ann Arbor, MI).

\section{Statistical analysis}

Data were presented as the mean \pm standard mean error (SEM). The statistical significance of differences between groups was assessed with Student's t test and one-way analysis of variance (ANOVA) using GraphPad Prism version 7 for Mac (GraphPad, La Jolla, CA). Tukey's post hoc test was performed when $\mathrm{p}$ values were $<0.05$. $\mathrm{p}<0.05$ was considered as statistically significant.

\section{Abbreviations}

CHC : chronic high dose captopril (40 mg/kg/day *21 days or more); TST : tail suspension test; FST : forced swimming test; LD : light-dark exploration; EPM : elevated plus maze; SI : social interaction test; Treg : regulatory $\mathrm{T}$ cell; Th2 : type 2 T helper cell; IL : interleukin; TNF : tumor necrosis factor; ANG II : angiotensin II; ACE : angiotensinconverting enzyme; CNS : central nervous system; IFN : interferon; KYN : kynurenine; BDNF : brain-derived neurotrophic factor; IDO : indoleamine 2,3-dioxygenase; KAT : kynurenine aminotransferase; KMO : kynurenine 3-monooxygenase; NMDA receptor : N-methyl-D-aspartate receptor; LPS : lipopolysaccharide; CRS : chronic restraint stress; Co-Imi : co-treatment of imipramine; Post-Imi : post-treatment of imipramine; GOT : glutamic oxaloacetic transaminase; GR : glucocorticoid receptor; qPCR : realtime polymerase chain reaction; HPA axis : hypothalamicpituitary-adrenal axis; 5- HT : 5-hydroxytryptamine; 5-HIAA : 5-hydroxyindoleacetic acid; CRH : corticotropinreleasing hormone.

\section{Author contributions}

Han A and Park HS wrote the first draft and was involved in most experiments. They contributed to conception and experimental design (Figures 1, 2, 3, 4, and 5). Yeo HL analyzed behavior data and qPCR (Figures 1, 2, and 4). Park MJ contributed to Western blot data and behavioral data analysis (Figures 1, 2, and 4). You MJ contributed behavioral data analysis (Figures 1 and 2). Choi HJ contributed to HPLC data analysis (Supplementary Figure 1). Kim SH and Lee SH drafted the article and revised it. Hong CW contributed to flow cytometry analysis, focusing on immune system (Figure 3). Kim B and Kwon MS designed this study and gave final approval of the revision. All authors commented on the manuscript and have approved the final version.

\section{ACKNOWLEDGMENTS}

This research was supported by Basic Science Research Program through the National

Research Foundation of Korea (NRF) funded by the Ministry of Education (NRF-2015R1D1A1A02062312), a grant of the Korean Mental Health Technology R\&D

Project, Ministry of Health \& Welfare, Republic of Korea (HM15C1094), and the Bio \& Medical Technology Development Program of the NRF funded by the Korean government, MSIP (2016M3A9E8941670).

\section{CONFLICTS OF INTEREST}

We have no conflicts of interest to declare.

\section{REFERENCES}

1. Ferrari AJ, Charlson FJ, Norman RE, Patten SB, Freedman G, Murray CJ, Vos T, Whiteford HA. Burden of depressive disorders by country, sex, age, and year: findings from the global burden of disease study 2010. PLoS Med. 2013; 10: e1001547. https://doi.org/10.1371/journal.pmed.1001547.

2. Moussavi S, Chatterji S, Verdes E, Tandon A, Patel V, Ustun B. Depression, chronic diseases, and decrements in health: results from the World Health Surveys. Lancet. 2007; 370: 851-8. https://doi.org/10.1016/S0140-6736(07)61415-9.

3. Krishnan V, Nestler EJ. The molecular neurobiology of depression. Nature. 2008; 455: 894-902. https://doi. org/10.1038/nature07455.

4. Baghai TC, Moller HJ, Rupprecht R. Recent progress in pharmacological and non-pharmacological treatment options of major depression. Curr Pharm Des. 2006; 12: 503-15. https://doi.org/10.2174/138161206775474422.

5. Ruhe HG, Huyser J, Swinkels JA, Schene AH. Switching antidepressants after a first selective serotonin reuptake inhibitor in major depressive disorder: a systematic review. J Clin Psychiatry. 2006; 67: 1836-55.

6. Blume J, Douglas SD, Evans DL. Immune suppression and immune activation in depression. Brain Behav Immun. 2011; 25: 221-9. https://doi.org/10.1016/j.bbi.2010.10.008.

7. Dantzer R, O'Connor JC, Lawson MA, Kelley KW. Inflammation-associated depression: from serotonin to kynurenine. Psychoneuroendocrinology. 2011; 36: 426-36. https://doi.org/10.1016/j.psyneuen.2010.09.012.

8. Lindqvist D, Janelidze S, Hagell P, Erhardt S, Samuelsson M, Minthon L, Hansson O, Bjorkqvist M, Traskman-Bendz L, Brundin L. Interleukin- 6 is elevated in the cerebrospinal fluid of suicide attempters and related to symptom severity. Biol Psychiatry. 2009; 66: 287-92. https://doi.org/10.1016/j. biopsych.2009.01.030.

9. Maes M. The cytokine hypothesis of depression: inflammation, oxidative \& nitrosative stress (IO\&NS) and leaky gut as new targets for adjunctive treatments in depression. Neuro Endocrinol Lett. 2008; 29: 287-91. 
10. Raison CL, Borisov AS, Majer M, Drake DF, Pagnoni G, Woolwine BJ, Vogt GJ, Massung B, Miller AH. Activation of central nervous system inflammatory pathways by interferon-alpha: relationship to monoamines and depression. Biol Psychiatry. 2009; 65: 296-303. https://doi. org/10.1016/j.biopsych.2008.08.010.

11. Uddin M, Koenen KC, Aiello AE, Wildman DE, de los Santos R, Galea S. Epigenetic and inflammatory marker profiles associated with depression in a community-based epidemiologic sample. Psychol Med. 2011; 41: 997-1007. https://doi.org/10.1017/S0033291710001674.

12. Muller N, Schwarz MJ. The immune-mediated alteration of serotonin and glutamate: towards an integrated view of depression. Mol Psychiatry. 2007; 12: 988-1000. https://doi. org/10.1038/sj.mp.4002006.

13. Dantzer R, O'Connor JC, Freund GG, Johnson RW, Kelley KW. From inflammation to sickness and depression: when the immune system subjugates the brain. Nat Rev Neurosci. 2008; 9: 46-56. https://doi.org/10.1038/nrn2297.

14. Kalkman HO, Feuerbach D. Antidepressant therapies inhibit inflammation and microglial M1-polarization. Pharmacol Ther. 2016; 163: 82-93. https://doi.org/10.1016/j. pharmthera.2016.04.001.

15. Yirmiya R, Rimmerman N, Reshef R. Depression as a microglial disease. Trends Neurosci. 2015; 38: 637-58. https://doi.org/10.1016/j.tins.2015.08.001.

16. Schnieder TP, Trencevska I, Rosoklija G, Stankov A, Mann JJ, Smiley J, Dwork AJ. Microglia of prefrontal white matter in suicide. J Neuropathol Exp Neurol. 2014; 73: 880-90. https://doi.org/10.1097/NEN.0000000000000107.

17. Torres-Platas SG, Cruceanu C, Chen GG, Turecki G, Mechawar N. Evidence for increased microglial priming and macrophage recruitment in the dorsal anterior cingulate white matter of depressed suicides. Brain Behav Immun. 2014; 42: 50-9. https://doi.org/10.1016/j.bbi.2014.05.007.

18. Kreisel T, Frank MG, Licht T, Reshef R, Ben-MenachemZidon O, Baratta MV, Maier SF, Yirmiya R. Dynamic microglial alterations underlie stress-induced depressive-like behavior and suppressed neurogenesis. Mol Psychiatry. 2014; 19: 699-709. https://doi.org/10.1038/mp.2013.155.

19. Han A, Yeo H, Park MJ, Kim SH, Choi HJ, Hong CW, Kwon MS. IL-4/10 prevents stress vulnerability following imipramine discontinuation. J Neuroinflammation. 2015; 12: 197. https://doi.org/10.1186/s12974-015-0416-3.

20. Slyepchenko A, Maes M, Kohler CA, Anderson G, Quevedo J, Alves GS, Berk M, Fernandes BS, Carvalho AF. T helper 17 cells may drive neuroprogression in major depressive disorder: proposal of an integrative model. Neurosci Biobehav Rev. 2016; 64: 83-100. https://doi.org/10.1016/j. neubiorev.2016.02.002.

21. Frank MG, Baratta MV, Sprunger DB, Watkins LR, Maier SF. Microglia serve as a neuroimmune substrate for stress-induced potentiation of CNS pro-inflammatory cytokine responses. Brain Behav Immun. 2007; 21: 47-59. https://doi.org/10.1016/j.bbi.2006.03.005.

22. Rodriguez-Perez AI, Borrajo A, Rodriguez-Pallares J, Guerra MJ, Labandeira-Garcia JL. Interaction between NADPH-oxidase and Rho-kinase in angiotensin II-induced microglial activation. Glia. 2015; 63: 466-82. https://doi. org/10.1002/glia.22765.

23. Kettenmann H, Hanisch UK, Noda M, Verkhratsky A. Physiology of microglia. Physiol Rev. 2011; 91: 461-553. https://doi.org/10.1152/physrev.00011.2010.

24. Kipnis J, Avidan H, Caspi RR, Schwartz M. Dual effect of CD4+CD25+ regulatory $\mathrm{T}$ cells in neurodegeneration: a dialogue with microglia. Proc Natl Acad Sci U S A. 2004; 101: 14663-9. https://doi.org/10.1073/pnas.0404842101.

25. Zhao W, Beers DR, Liao B, Henkel JS, Appel SH. Regulatory $\mathrm{T}$ lymphocytes from ALS mice suppress microglia and effector $\mathrm{T}$ lymphocytes through different cytokine-mediated mechanisms. Neurobiol Dis. 2012; 48: 418-28. https://doi.org/10.1016/j.nbd.2012.07.008.

26. Miller AH. Depression and immunity: a role for $\mathrm{T}$ cells? Brain Behav Immun. 2010; 24: 1-8. https://doi. org/10.1016/j.bbi.2009.09.009.

27. Workman CJ, Szymczak-Workman AL, Collison LW, Pillai MR, Vignali DA. The development and function of regulatory T cells. Cell Mol Life Sci. 2009; 66: 2603-22. https://doi.org/10.1007/s00018-009-0026-2.

28. Park HS, Park MJ, Kwon MS. Central nervous systemperipheral immune system dialogue in neurological disorders: possible application of neuroimmunology in urology. Int Neurourol J. 2016; 20: S8-14.

29. Shrestha S, Noh JM, Kim SY, Ham HY, Kim YJ, Yun YJ, Kim MJ, Kwon MS, Song DK, Hong CW. Angiotensin converting enzyme inhibitors and angiotensin II receptor antagonist attenuate tumor growth via polarization of neutrophils toward an antitumor phenotype. Oncoimmunology. 2016; 5: e1067744. https://doi.org/10.1 080/2162402X.2015.1067744.

30. Davidson RJ, Pizzagalli D, Nitschke JB, Putnam K. Depression: perspectives from affective neuroscience. Annu Rev Psychol. 2002; 53: 545-74. https://doi.org/10.1146/ annurev.psych.53.100901.135148.

31. Hasler G, Drevets WC, Manji HK, Charney DS. Discovering endophenotypes for major depression. Neuropsychopharmacology. 2004; 29: 1765-81. https:/doi. org/10.1038/sj.npp.1300506.

32. Lanquillon S, Krieg JC, Bening-Abu-Shach U, Vedder H. Cytokine production and treatment response in major depressive disorder. Neuropsychopharmacology. 2000; 22 : 370-9. https://doi.org/10.1016/S0893-133X(99)00134-7.

33. Han A, Sung YB, Chung SY, Kwon MS. Possible additional antidepressant-like mechanism of sodium butyrate: targeting the hippocampus. Neuropharmacology. 2014; 81: 292-302. https://doi.org/10.1016/j.neuropharm.2014.02.017. 
34. Berton O, Nestler EJ. New approaches to antidepressant drug discovery: beyond monoamines. Nat Rev Neurosci. 2006; 7: 137-51. https://doi.org/10.1038/nrn1846.

35. Oh YB, Kim JH, Park BM, Park BH, Kim SH. Captopril intake decreases body weight gain via angiotensin-(1-7). Peptides. 2012; 37: 79-85.

36. Dowlati Y, Herrmann N, Swardfager W, Liu H, Sham L, Reim EK, Lanctot KL. A meta-analysis of cytokines in major depression. Biol Psychiatry. 2010; 67: 446-57. https://doi.org/10.1016/j.biopsych.2009.09.033.

37. Raison CL, Capuron L, Miller AH. Cytokines sing the blues: inflammation and the pathogenesis of depression. Trends Immunol. 2006; 27: 24-31. https://doi.org/10.1016/j. it.2005.11.006.

38. MacQueen G, Frodl T. The hippocampus in major depression: evidence for the convergence of the bench and bedside in psychiatric research? Mol Psychiatry. 2011; 16: 252-64. https://doi.org/10.1038/mp.2010.80.

39. Webster JC, Oakley RH, Jewell CM, Cidlowski JA. Proinflammatory cytokines regulate human glucocorticoid receptor gene expression and lead to the accumulation of the dominant negative beta isoform: a mechanism for the generation of glucocorticoid resistance. Proc Natl Acad Sci U S A. 2001; 98: 6865-70. https://doi.org/10.1073/ pnas. 121455098 .

40. Czeh B, Fuchs E, Wiborg O, Simon M. Animal models of major depression and their clinical implications. Prog Neuropsychopharmacol Biol Psychiatry. 2016; 64: 293-310. https://doi.org/10.1016/j.pnpbp.2015.04.004.

41. Miller AH. Norman Cousins Lecture. Mechanisms of cytokineinduced behavioral changes: psychoneuroimmunology at the translational interface. Brain Behav Immun. 2009; 23: 149-58. https://doi.org/10.1016/j.bbi.2008.08.006.

42. Kim SJ, Lee H, Lee G, Oh SJ, Shin MK, Shim I, Bae H. $\mathrm{CD} 4+\mathrm{CD} 25+$ regulatory $\mathrm{T}$ cell depletion modulates anxiety and depression-like behaviors in mice. PLoS One. 2012; 7: e42054. https://doi.org/10.1371/journal.pone.0042054.

43. Basu R, Whitley SK, Bhaumik S, Zindl CL, Schoeb TR, Benveniste EN, Pear WS, Hatton RD, Weaver CT. IL-1 signaling modulates activation of STAT transcription factors to antagonize retinoic acid signaling and control the TH17 cell-iTreg cell balance. Nat Immunol. 2015; 16: 286-95. https://doi.org/10.1038/ni.3099.

44. Fujimoto M, Nakano M, Terabe F, Kawahata H, Ohkawara T, Han Y, Ripley B, Serada S, Nishikawa T, Kimura A, Nomura S, Kishimoto T, Naka T. The influence of excessive IL-6 production in vivo on the development and function of Foxp3+ regulatory T cells. J Immunol. 2011; 186: 32-40. https://doi.org/10.4049/jimmunol.0903314.

45. Reshef R, Kreisel T, Beroukhim Kay D, Yirmiya R. Microglia and their CX3CR1 signaling are involved in hippocampal- but not olfactory bulb-related memory and neurogenesis. Brain Behav Immun. 2014; 41: 239-50. https://doi.org/10.1016/j.bbi.2014.04.009.
46. Hwang J, Zheng LT, Ock J, Lee MG, Kim SH, Lee HW, Lee WH, Park HC, Suk K. Inhibition of glial inflammatory activation and neurotoxicity by tricyclic antidepressants. Neuropharmacology. 2008; 55: 826-34. https://doi. org/10.1016/j.neuropharm.2008.06.045.

47. Sukoff Rizzo SJ, Neal SJ, Hughes ZA, Beyna M, Rosenzweig-Lipson S, Moss SJ, Brandon NJ. Evidence for sustained elevation of IL-6 in the CNS as a key contributor of depressive-like phenotypes. Transl Psychiatry. 2012; 2: e199. https://doi.org/10.1038/tp.2012.120.

48. Van Bogaert T, Vandevyver S, Dejager L, Van Hauwermeiren F, Pinheiro I, Petta I, Engblom D, Kleyman A, Schutz G, Tuckermann J, Libert C. Tumor necrosis factor inhibits glucocorticoid receptor function in mice: a strong signal toward lethal shock. J Biol Chem. 2011; 286: 2655567. https://doi.org/10.1074/jbc.M110.212365.

49. Noh MY, Lim SM, Oh KW, Cho KA, Park J, Kim KS, Lee SJ, Kwon MS, Kim SH. Mesenchymal stem cells modulate the functional properties of microglia via TGF- $\beta$ secretion. Stem Cells Transl Med. 2016; 5: 1538-49. https://doi. org/10.5966/sctm.2015-0217.

50. Conrad CD, Wright RL, McLaughlin KJ. Stress and Vulnerability to Brain Damage. (Elsevier Ltd., 2010).

51. Duman RS. Depression: a case of neuronal life and death? Biol Psychiatry. 2004; 56: 140-5. https://doi.org/10.1016/j. biopsych.2004.02.033.

52. Caughey GH. Mast cell tryptases and chymases in inflammation and host defense. Immunol Rev. 2007; 217: 141-54. https://doi.org/10.1111/j.1600-065X.2007.00509.x.

53. van de Wal RM, Plokker HW, Lok DJ, Boomsma F, van der Horst FA, van Veldhuisen DJ, van Gilst WH, Voors AA. Determinants of increased angiotensin II levels in severe chronic heart failure patients despite ACE inhibition. Int J Cardiol. 2006; 106: 367-72. https://doi.org/10.1016/j. ijcard.2005.02.016.

54. Urata H, Kinoshita A, Misono KS, Bumpus FM, Husain A. Identification of a highly specific chymase as the major angiotensin II-forming enzyme in the human heart. J Biol Chem. 1990; 265: 22348-57.

55. Geary KM, Hunt MK, Peach MJ, Gomez RA, Carey RM. Effects of angiotensin converting enzyme inhibition, sodium depletion, calcium, isoproterenol, and angiotensin II on renin secretion by individual renocortical cells. Endocrinology. 1992; 131: 1588-94. https://doi.org/10.1210/ endo.131.4.1396304.

56. Benedict CR, Francis GS, Shelton B, Johnstone DE, Kubo SH, Kirlin P, Nicklas J, Liang CS, Konstam MA, Greenberg B, Yusuf S; The SOLVD Investigators. Effect of long-term enalapril therapy on neurohormones in patients with left ventricular dysfunction. Am J Cardiol. 1995; 75: 1151-7.

57. Hollenberg NK. Pharmacologic interruption of the reninangiotensin system and the kidney: differential responses to angiotensin-converting enzyme and renin inhibition. J Am Soc Nephrol. 1999; 101: S239-42. 
58. Lee AF, MacFadyen RJ, Struthers AD. Neurohormonal reactivation in heart failure patients on chronic ACE inhibitor therapy: a longitudinal study. Eur J Heart Fail. 1999; 1: 401-6.

59. Gard PR. The role of angiotensin II in cognition and behaviour. Eur J Pharmacol. 2002; 438: 1-14. https://doi. org/10.1016/S0014-2999(02)01283-9.

60. Hoch NE, Guzik TJ, Chen W, Deans T, Maalouf SA, Gratze P, Weyand C, Harrison DG. Regulation of T-cell function by endogenously produced angiotensin II. Am J Physiol Regul Integr Comp Physiol. 2009; 296: R208-16. https://doi. org/10.1152/ajpregu.90521.2008.

61. Platten M, Youssef S, Hur EM, Ho PP, Han MH, Lanz TV, Phillips LK, Goldstein MJ, Bhat R, Raine CS, Sobel RA, Steinman L. Blocking angiotensin-converting enzyme induces potent regulatory $\mathrm{T}$ cells and modulates $\mathrm{TH} 1-$ and TH17-mediated autoimmunity. Proc Natl Acad Sci U S A. 2009; 106: 14948-53. https://doi.org/10.1073/ pnas.0903958106.

62. Gelinas L, Falkenham A, Oxner A, Sopel M, Legare JF. Highly purified human peripheral blood monocytes produce IL-6 but not TNFalpha in response to angiotensin II. J Renin Angiotensin Aldosterone Syst. 2011; 12: 295-303. https://doi.org/10.1177/1470320310391332.

63. Pasare C, Medzhitov R. Toll pathway-dependent blockade of CD4+CD25+ T cell-mediated suppression by dendritic cells. Science. 2003; 299: 1033-6. https://doi.org/10.1126/ science. 1078231.

64. Dominitzki S, Fantini MC, Neufert C, Nikolaev A, Galle PR, Scheller J, Monteleone G, Rose-John S, Neurath
MF, Becker C. Cutting edge: trans-signaling via the soluble IL-6R abrogates the induction of FoxP3 in naive CD4+CD25 T cells. J Immunol. 2007; 179: 2041-5.

65. Benicky J, Sanchez-Lemus E, Honda M, Pang T, Orecna M, Wang J, Leng Y, Chuang DM, Saavedra JM. Angiotensin II AT1 receptor blockade ameliorates brain inflammation. Neuropsychopharmacology. 2011; 36: 857-70. https://doi. org/10.1038/npp.2010.225.

66. Lanz TV, Ding Z, Ho PP, Luo J, Agrawal AN, Srinagesh H, Axtell R, Zhang H, Platten M, Wyss-Coray T, Steinman L. Angiotensin II sustains brain inflammation in mice via TGF-beta. J Clin Invest. 2010; 120: 2782-94. https://doi. org/10.1172/JCI41709.

67. Rodriguez-Pallares J, Rey P, Parga JA, Munoz A, Guerra MJ, Labandeira-Garcia JL. Brain angiotensin enhances dopaminergic cell death via microglial activation and NADPH-derived ROS. Neurobiol Dis. 2008; 31: 58-73. https://doi.org/10.1016/j.nbd.2008.03.003.

68. Rutledge T, Reis VA, Linke SE, Greenberg BH, Mills PJ. Depression in heart failure a meta-analytic review of prevalence, intervention effects, and associations with clinical outcomes. J Am Coll Cardiol. 2006; 48: 1527-37. https://doi.org/10.1016/j.jacc.2006.06.055.

69. Kwon MS, Seo YJ, Lee JK, Lee HK, Jung JS, Jang JE, Park SH, Suh HW. The repeated immobilization stress increases IL-1beta immunoreactivities in only neuron, but not astrocyte or microglia in hippocampal CA1 region, striatum and paraventricular nucleus. Neurosci Lett. 2008; 430: 258-63. https://doi.org/10.1016/j.neulet.2007.11.006. 